\title{
RUANG IDEAL BALI \\ DALAM TEKANAN GLOBALISASI
}

\author{
Oleh: \\ I Putu Gede Suyoga \\ Dosen Sekolah Tinggi Desain Bali, Denpasar \\ e-mail: gsuyoga@yahoo.com
}

\begin{abstract}
The development of space understanding in the Balinese architecture is deeply influenced by the theology, philosophy, and concepts of the Hinduism. Therefore, the real existence of the Balinese spatial layout is the grounding of the Hindu ideology. The Hindu teachings such as tat twam asi, bhuana agung - bhuana alit, panca maha bhuta, tri hita karana, tri bhuwana, purusha-pradhana, and others have been instilled in the practical principle of the Balinese architecture such as tri mandala, sanga mandala, tri angga, sukat 'measurement', natah, decoration, color, texture, and others. The Hindu spirituality in the Balinese and spatial architecture is manifested by: (1) Arrangement of the physical structure, building, landscape, anthropometry, topography, geography, and local climate, and aesthetics (form of yoga). (2) Various meanings and symbols on the spatial and physical layout of the building (form of yantra and tantra). (3) Procedures for building, accompanying rituals during pre-construction, construction, and post-construction periods symbolize the 'living building figures' (mantra and mudra forms).
\end{abstract}

Keywords: Ideal Space, Globalization

\begin{abstract}
Abstrak
Pengembangan pemahaman ruang dalam arsitektur Bali sangat dipengaruhi oleh teologi, filosofi, dan konsep ajaran agama Hindu, dengan demikian eksistensi tata ruang Bali sejatinya adalah pembumian ideologi Hindu. Ajaran Hindu seperti: tat twam asi, bhuana agung - bhuana alit, panca maha bhuta, tri hita karana, tri bhuwana, purusha-pradhana, dan lainnya, menjadi prinsip praktis kearsitekturan, seperti, tri mandala, sanga mandala, tri angga, sukat 'ukuran', natah, ragam hias, warna, tekstur dan lainnya. Spiritualitas ke-Hinduan dalam pola ruang dan tata bangunan arsitektur Bali diwujudkan dengan: (1) Penataan struktur fisik, bangunan, landsekap, kesesuaian antropometri pemilik, topografi, geografi, dan iklim setempat, serta estetika (bentuk olah yoga). (2) Beraneka makna dan simbol-simbol pada tata ruang dan fisik bangunannya (bentuk olah yantra, dan tantra). (3) Tata cara mendirikan bangunan, ritual yang menyertai selama masa pra konstruksi, konstruksi, dan pasca konstruksi sebagai bawa maurip 'sosok bangunan yang hidup' (bentuk olah mantra, dan mudra).
\end{abstract}

Kata kunci: Ruang Ideal, Globalisasi

\section{PENDAHULUAN}

Filosofi yang mendasari tata ruang dalam arsitektur Bali, tidak dapat dipisahkan dari nilai kehinduan. Ajaran Hindu yang mempermulia lokal genius masyarakat Nusantara telah membentuk suatu bentukan filosofi baru masyarakat Nusantara dan mempengaruhi segala tatanan

24 
kehidupan masyarakatnya, termasuk masyarakat Bali.

Ruang bagi masyarakat Bali dapat dipahami dalam wujudnya secara fisik yang dapat dilihat, dirasakan, dan ditempati. Pemahaman mereka juga berkembang secara filosofis sesuai konsep teologi yang berkembang pada masanya. Konsep keyakinan lokal Nusantara, yang kemudian dipermulia oleh teologi dan ajaran Hindu-Budha India telah menjadi rujukan pemahaman mereka terhadap eksistensi ruang yang ada disekitarnya.

Pengembangan dari orientasi ruang tersebut, kemudian diterjemahkan dalam desain rancang permukiman mereka yang berkembang dari pola linier ke spasial "catus patha". Catus patha terbentuk dari silang sumbu bumi (Utara-Selatan) dengan sumbu matahari (Timur-Barat). Penataan kebutuhan ruang-ruang untuk zona pemujaan (parhyangan), zona aktivitas manusia ( $p a-$ wongan) dan zona pelayanan/service (palemahan) dilakukan dengan mengacu pada konsep mandala yang dikembangkan dari tri mandala menjadi sanga mandala. Ruang-ruang pun kemudian terbentuk dengan sembilan zonasi sebagai letak aktivitas spiritual, komunal dan komersial yang bersifat sakral-semi-profan.

Karya arsitektur Bali, dalam kedudukannya sebagai wadah kegiatan manusia Bali, merupakan pengakrab antara manusia dengan alam lingkungannya. Hal ini terlihat dari penataan ruang berlandaskan pada "panca maha bhuta" yang diyakini ada pada diri manusia dan alam semesta, sebagai percerminan mikrokosmos (bhuana alit) dan makrokosmos (bhuana agung). Manusia Bali dengan sosiosistem berinteraksi dalam ekosistem mewujudkan karya arsitektur sebagai salah hasil teknosistem. Jadi dapat dipahami, arsitektur Bali sangat menekankan pada keselarasan dengan alam, ia tidak tunduk pada alam ataupun menentang alam, sesuai maksud yang terkandung dalam pengertian tat twam asi.

Ungkapan konsepsi dalam arsitektur Bali pada hakekatnya merupakan dasar-dasar perwujudan arsitektur Bali ke dalam wujud yang lebih nyata dari niskala (ideal) menjadi lebih sekala (riil). Dasar-dasar filosofi tersebut meliputi: (1) Pandangan hidup masyarakat Hindu Bali, (2) Norma-norma agama dan kepercayaan, dan (3) Sikap hidup masyarakatnya (Wikipedia, 2016).

Pandangan hidup masyarakat Hindu Bali meyakini adanya unsur-unsur pembentuk yang sama antara manusia dan alam (panca maha bhuta), secara tidak langsung akan menjadi panduan dalam menempatkan diri di alam lingkungan sebagai aspek isi dan wadah atau manusia dengan karya arsitektur. Norma-norma agama dan kepercayaan bertolak dari lima dasar kepercayaan masyarakat Hindu yang tertuang dalam panca sradha, sedangkan sikap hidup masyarakat Bali memiliki suatu sikap terhadap sesamanya, alam beserta isinya sebagai ciptaan Tuhan, dan hal ini tercermin dalam pengertian tat twam asi.

Dasar-dasar filosofi inilah yang akhirnya melahirkan konsepsi perwujudan atau konsep praktik tata ruang dan bangunan arsitektur Bali. Pengertian arsitektur tradisional Balipun rupanya dikembangkan dari pemahaman ini, seperti dipetik oleh Prof. Rumawan Salain dari Perda No. 5 Tahun 2005, tentang Persyaratan Arsitektur Bangunan Gedung, menyebutkan Arsitektur Tradisional Bali adalah tata ruang dan tata bentuk yang pembangunannya didasarkan atas nilai dan norma-norma, baik yang tertulis maupun tidak tertulis yang diwariskan secara turun-temurun (Salain, 2013: 11).

Apa saja konsep praktik arsitektur Bali berupa pola ruang dan tata bangunan yang lahir dari kristalisasi filosofi agama Hindu di atas, dan bagaimana konsepsi-konsepsi tersebut dijaga melalui norma-norma, serta pengaruhnya akibat tekanan globalisasi dengan agen pariwisata dan modernisasi ? Pembahasan berikut ini akan menguraikannya.

\section{PEMBAHASAN}

Pemahaman terhadap ruang pada masyarakat tradisional Bali dapat dirunut dari perkembangan pemahaman masyarakat Bali Mula yang orientasi ruangnya adalah ruang antara langit yang ada di atas dan bumi tempat mereka berpijak (langit-bumi), pada masyarakat Bali Aga yang berlatarbelakang tinggal di pegunungan Aga di Jawa Timur, orientasi ruang mereka adalah ruang daratan antara kaja 'gunung' dan kelod 'laut' (kaja-kelod atau gunung-laut), dan berikutnya pada masyarakat Bali Arya/Majapahit atau Bali Pertengahan yang umumnya tinggal di dataran memandang ruang adalah antara arah matahari terbit dan terbenam (kanginkauh atau Timur-Barat) (Suyoga, 2016: 287).

Uraian tersebut menyangkut pemahaman 
masyarakat Bali terhadap ruang secara fisik, dalam perkembangannya pemahaman ruang juga dipengaruhi filosofi ajaran agama Hindu. Arsitektur yang mewadahi setiap bentuk kegiatan menjadikan bentuk-bentuk perwujudan ruang yang tidak terbatas adanya (Gelebet, 2002: 5). Falsafah ruang di Bali berkembang dari ajaran tat twam asi dalam Hindu. Tat twam asi berarti "itu adalah aku". Inti ajaran tat twam asi adalah menjaga keharmonisan dalam kehidupan, terhadap segala bentuk ciptaan Tuhan, termasuk dunia ini. Ajaran Hindu meyakini dunia (alam semesta) ini diciptakan Tuhan dalam manifestasinya sebagai Brahma, sehingga dunia ini disebut sebagai "Telur Brahma" (Brahma-Anda atau Brahmanda). Pernyataan ini menuntun pada pemahaman konsep ruang arsitektur dalam arti yang sejati, yakni konsep ruang yang diilhami oleh kedalaman jiwa manusia yang peka dimensi kosmologi, tumbuh dari penghayatan keagamaan.

Tat twam asi mengandung makna konsep ruang dalam keseimbangan kosmos (balance cosmologi). Ruang makro (bhuwana agung) senantiasa harus seimbang dengan ruang mikro (bhuwana alit). Struktur ruang makrokosmos, secara vertikal tersusun atas tiga lapisan yang dianalogikan sebagai tiga dunia (Tribhuwana). Struktur ruang Tri Bhuwana atau Tri Loka ini terdiri dari: Bumi dan alam lingkungannya sebagai "alam paling bawah", disebut Bhur loka; "Alam tengah" adalah alam roh-roh suci, disebut Bhuwah loka; dan "Alam atas" adalah alam para Dewa, disebut Swah loka. Struktur Tri Bhuwana dalam kosmos juga dapat dianalogikan dengan "litosfir" untuk "alam bawah", "hydrosfir" untuk "alam tengah" dan "atmosfir" untuk "alam atas".

Falsafah Tri Bhuwana kemudian dijabarkan ke dalam konsep Tri Hita Karana, pendekatannya dilakukan ke dalam perencanaan ruang secara makro (macro planing) dan perencanaan ruang mikro (micro design) menjadi tiga kelompok ruang (tri mandala): (1) ruang sakral (parhyangan), (2) ruang untuk aktivitas manusia (pawongan), dan (3) ruang yang bersifat pelayanan/servis (palemahan). Pengelompokan ruang ini berlaku dari lingkungan terbesar sampai elemen ruang terkecil.

Secara filosofis, Tri Hita Karana sendiri mengandung pengertian sebagai tiga kutub yang menjadikan suatu kehidupan di bumi, terdiri dari jiwa (atma), fisik (angga), dan tenaga (ka- $y a)$. Falsafah ruang ini kemudian melandasi pengembangan konsepsi ruang dalam tata ruang Bali yang berpedoman pada perkembangan konsep andabhuwana, tri mandala, dan catuspatha.

\subsection{Orientasi dan Konsep Ruang}

Orientasi ruang tradisional Bali bersumber dari konsep Andabhuwana atau Bhuwananda yang diartikan bumi atau "telur jagat". Berdasarkan konsep ini, konsep ruang di Bali berorientasi pada potensi alam setempat. Gelebet (2002: 11) menyatakan konseptul perancangan arsitektur Bali didasarkan pada tata nilai ruang atau orientasi ruang. Orientasi ruang tersebut dibentuk oleh tiga sumbu. Pertama, sumbu kosmos (bhur, bhuah, swah atau litosfer, hydrosfer, atmosfer) atau sumbu langit-bumi (akasa-pertiwi). Kedua, sumbu ritual kangin-kauh (terbitterbenamnya matahari), dan ketiga, sumbu natural kaja-kelod, gunung-laut, masing-masing dengan daerah tengah yang bernilai madia.

Konsep ruang yang membentuk tata nilai ruang disebut tri mandala. Tri mandala merupakan ungkapan tiga tata nilai wilayah ruang, yang terdiri dari: (1) ruang sakral/spiritual, (2) ruang profan/komunal, dan (3) ruang pelayanan/ komersial. Struktur tata ruang tri mandala ini berpedoman pada orientasi gunung-laut (kajakelod) dan orientasi terbit-terbenamnya matahari (kangin-kauh).

Konsekuensi orientasi gunung-laut, maka tata ruang di bagian hulu digunakan untuk kegiatan spiritual dan ruangnya disebut "utama mandala". Ruang yang bersifat komunal berada di bagian tengah, disebut "madya mandala". Sedangkan ruang yang bersifat komersial atau pelayanan/servis, ditempatkan di bagian hilir dan ruangnya disebut "nista mandala".

Jika konsep ruang tri mandala ini berpedoman pada orientasi terbit dan terbenamnya matahari, maka tata ruang paling timur adalah "utama mandala", bagian tengah "madya mandala" dan yang paling barat adalah "nista mandala".

Jika konsep ruang tri mandala dikembangkan dari pola linier ke spatial, maka akan diperoleh tata zoning dalam suatu tapak (site area) berupa sembilan wilayah tata nilai ruang, yang disebut "sanga mandala" (Sudibya, 2008: 25).

Konsep ruang Bali lainnya adalah catuspatha. Catuspatha merupakan ungkapan pola ruang 
salib sumbu, sebagai persilangan sumbu bumi (kaja - kelod) 'gunung - laut', dengan sumbu matahari (kangin - kauh) 'Timur - Barat', yang berorientasi ke titik pusat perempatan jalan (pempatan agung) di pusat permukiman. Sepadan dengan pengertian yang diungkapkan oleh Atmaja (2003: 1) perempatan sebagai titik yang mempertemukan empat ruas jalan raya yang kemudian disebut dengan bermacam nama: margi nyatur desa, pemelapas agung, margi pat, margi betel, margi dane-dane dan lain-lainnya.

Nilai "titik pusat" dalam konsep catuspatha 'pempatan agung' adalah nol atau kosong (pralina), dengan makna "mahasempurna". Eksistensinya diperkuat lagi dengan ketersediakan tanah kosong (karang tuang) seluas satu persil, pada setiap sudut perempatan yang berfungsi sebagai "ruang terbuka hijau".

Pengembangan konsep ruang terbuka yang bersifat makro ini juga terdapat di tengah-tengah pemukiman yang disebut karang embang, sedangkan yang ada di luar pemukiman disebut karang bengang sebagai margin antar permukiman, dan semakin mikro menjadi ruang terbuka yang ada di dalam setiap titik tengah persil lahan pekarangan dinamakan natah ataupun natar.

\subsection{Kesadaran Spiritual akan Keruangan}

Berangkat dari kesadaran spiritual ke-Hinduan manusia Bali memahami tentang hakekat hidup yang sejati, yaitu untuk senantiasa menjalin hubungan harmoni antara manusia dengan Tuhan, manusia dengan manusia, dan manusia dengan lingkungan, sebagai tiga unsur penyebab kebaikan, kelestarian, atau kesejahteraan (tri hita karana). Filosofi tri hita karana kemudian diringkas menjadi unsur: parhyangan, pawongan, dan palemahan yang aplikatif sesuai desa 'tempat', kala 'waktu', dan patra 'situasi/ kondisi'.

Secara arsitektural hubungan tri hita karana dengan susunan kosmos dapat diperinci sebagai berikut: (1) Manusia: jiwa, tenaga, jasad (fisik). (2). Rumah: sanggah/pemerajan, penghuni, pekarangan. (3) Banjar: pura banjar, warga banjar, karang banjar. (4) Desa: pura kahyangan tiga, krama 'masyarakat', wilayah desa. (5) Alam semesta: Paramatman 'Tuhan', energi alam, panca maha bhuta (Sulistyawati, 2013: 245; Suardana, 2015: 118).

Tri hita karana memberi turunan prinsip praktis dalam arsitektur Bali, yakni: konsep tri angga 'tiga susunan badan' atau dengan kata lain "tiga nilai fisik", yaitu: kepala (utama angga), badan (madya angga), dan kaki (nista angga). Konsep hirarkhi ruang tri angga ini di bhuana agung disebut tri loka atau tri mandala, yakni: swahloka/utama mandala (alam atas), bwahloka/madya mandala (alam tengah), dan bhurloka/nista mandala (alam bawah) (Gelebet, 2002).

Spiritualitas ke-Hinduan dalam pola ruang dan tata bangunan arsitektur Bali diwujudkan dengan: (1) Penataan struktur fisik, bangunan, landsekap, kesesuaian antropometri pemilik, topografi, geografi, dan iklim setempat, serta estetika sebagai pengejawantahan bentuk olah yoga. (2) Beraneka makna dan simbol-simbol pada tata ruang dan fisik bangunannya merupakan bentuk olah yantra, dan tantra). (3) Tata cara mendirikan bangunan, ritual yang menyertai selama masa pra konstruksi, konstruksi, dan pasca konstruksi sebagai bawa maurip 'sosok bangunan yang hidup' sebagai bentuk olah mantra, dan mudra).

\subsection{Ruang Bali di Ranah Global}

Filsafat tentang kekosongan secara arsitektural disebut ruang. Penekanan pada ruang kosong sebagai hakikat penciptaan ruang pernah diungkapkan berabad-abad yang lalu oleh Lao Tzu sekitar 550 S.M. Perkembangan arsitektur berikutnya yang berlangsung terus-menerus berakar dari perubahan konsep-konsep ruang. Estetika arsitektur akhir abad ke-19 menyatakan bahwa eksistensi ruang menjadi esensi dari arsitektur. Pada awal abad ke-20, beberapa trend artistik tertentu yang memahami kata-kata bijak kuno dari Timur yang mengatakan bahwa massa adalah abdi dari kekosongan, akhirnya sampai pada ketetapan akan dematerialisasi (peniadaan materi) terhadap soliditas massa. Ungkapan terkenal pada masa itu menyebutkan "tujuan hasil cipta kita, adalah seni ruang, esensi dari arsitektur".

Ruang dari sudut terbentuknya ada dua, yakni: (1) ruang adalah kosong menurut versi Timur dan (2) versi Barat menyatakan ruang terbentuk dari batas-batas. Contoh pada rumah tradisional Bali yang disebut natah dapat dijadikan representasi dari ruang. Orang timur "Bali" menyebut ruang itu adalah natah "kosong", sedangkan cara pandang Barat memandang ruang atau natah tersebut terbentuk karena adanya 
Bale Daja, Bale Delod, Bale Dangin, dan Bale Dauh.

Natah menjadi wujud fisik keruangan yang secara filosofi menjadi tempat pertemuan bapa akasa - ibu pertiwi 'unsur langit - bumi, atau purusha - pradhana 'unsur maskulin - feminin'. Natah berfungsi sebagai wadah sebuah kehidupan baru dimulai dan berakhir nantinya. Secara sosial natah berfungsi sebagai ruang interaksi, penerimaan tamu terkait perayaan/upacara, tempat prosesi ritual berlangsung, sedangkan secara arsitektural natah berfungsi sebagai perluasan ruang (bale-bale), titik orientasi dan sirkulasi. Fungsi kesehatannya adalah penyediaan ruang terbuka untuk mempermudah memperoleh sinar matahari, pencahayaan, penghawaan, dan aspek utilitas lainnya (Suardana, 2015: 60).

Gabungan kedua pandangan Timur dan Barat tentang ruang adalah analog dengan volume atau isi. Ruang adalah volume yang terbentuk oleh karena batas-batas "fisik" (nyata) ataupun areal dalam batas-batas "metafisik" (maya). Pengertian ini memberi pemahaman, timbulnya ruang-ruang sakral (kawasan suci) karena adanya batas-batas fisik pagar pura, beji dan situs lainnya dengan radiusnya masing-masing sebagai ruang kekeran 'keramat' yang disucikan, seperti: apenyengker 'batas pekarangan', apenimpug 'sejauh lemparan', dan apeneleng 'sejauh mata memandang'.

Di sisi lain, kapitalisme dengan mengusung konsep profan materialis dan hedonis, wajar berpandangan ruang tersebut sama saja. Hal ini sesuai pendapat Halim, (2002: xxi) bahwa kapitalisme memang menjamin kebebasan individu. Ia memberi ruang bagi siapa saja untuk menjadi dirinya sendiri. Orang menjadi bebas menafsirkan nilai yang selama ini berlaku kolektif menjadi sebuah pilihan privat. Kapitalisme dalam wajah pariwisata misalnya, akan memandang semua ruang potensial dikomodifikasi menjadi area atau kawasan yang dapat dibangun fasilitas penunjang pariwisata.

Ruang kawasan suci memiliki kesamaan dengan konsep ruang konsentrik yang pertama kali disampaikan oleh E.W. Burgess (Yunus, 2004:5; Jayadinata, 1992: 105 dalam Adhika, 2012: 5) yang menyatakan bahwa kota terdiri dari zonazona konsentrik yang masing-masing zone menunjukkan pola penggunaan lahan yang berbeda. Pada lingkaran paling dalam terdapat pusat kota; kemudian lingkaran berikutnya adalah rumah-rumah sewa, industri, dan perumahan buruh; lingkaran berikutnya adalah jalur wisma buruh yang merupakan perumahan karyawan pabrik, kemudian lingkaran berikutnya adalah rumah kelas madya, dan pada lingkaran luar adalah rumah-rumah kelas madya dan atas. Namun kemudian, konsep ini mendapat kritik dari Davie (dalam Yunus, 2004:13) terhadap zone yang tidak teratur dan masuk pada wilayah lain, seperti yang disampaikan oleh Burgess, serta perkembangan lebih banyak mengikuti jalur transportasi yang ada.

Ada kesamaan konsep yang disampaikan E.W. Burgess dan bhisama tentang kawasan suci. Namun demikian, kenyataan konsep itu sulit diterapkan di lapangan, karena terbentur dengan kondisi fisik wilayah, maupun satuan-satuan komunitas yang sulit untuk dipisahkan satu dengan yang lainnya. Oleh karena itu, konsep konsentrik maupun bhisama merupakan konsep imajiner sebagai pembatas dari pengklasifikasian kawasan.

Kawasan suci pura, terutama pura yang memiliki lingkungan alam yang indah, juga dianggap memiliki daya tarik bagi kunjungan wisatawan domestik maupun mancanegara. Gerakan komodifikasipun mendekati kawasan suci tersebut. Maka terjadilah sejumlah kasus-kasus penyerobotan kawasan suci untuk berbagai fasilitas pendukung pariwisata oleh pihak investor yang tidak sadar, kalau lingkungan Bali menghormati batas-batas metafisik tersebut. Fakta terjadinya sejumlah konflik belakangan ini menjadi bukti sudah demikian kerasnya kapitalisme global melalui sektor pariwisata dan modernisasi memberi tekanan kepada idealnya aplikasi filosofi dan konsep ruang Bali yang telah terbukti bertahun-tahun memberi harmoni dan rasa damai pada perikehidupan masyarakat Bali.

Tekanan globalisasi telah menyebabkan perubahan orientasi pusat desa. Sukawati, (2004:73) mengutip pendapat Cantika, dkk. (1991:37) melihat pusat orientasi desa pada masyarakat agraris, erat kaitannya dengan keyakinan-keyakinan masyarakat yang dilandasi oleh konsep-konsep ataupun nilai-nilai religius Hinduistis, sedangkan pusat orientasi masyarakat industri erat kaitannya dengan nilai ekonomis. Hal ini sejalan dengan pendapat Reksohadiprodjo dan Karseno (1993:19-20), bahwa pemanfaatan tanah di perkotaan ditentukan oleh 
scate economics dan anglomerasi.

Peran pemerintah dan kelembagaan/organisasi masyarakat (Hindu) dan lainnya dalam perumusan regulasi maupun pengawasan aplikasinya di lapangan menjadi penting dikedepankan, disamping partisipasi aktif pihak swasta (pengusaha) untuk meningkatkan pemahamannya dalam pemanfaatan ruang bagi kepentingan investasi usaha, dilakukan pada zona-zona yang telah ditetapkan dalam Perda Rencana Umum Tata Ruang (RUTR) ataupun RUTRK (Kawasan).

Pemanfaatan ruang-ruang kosong berupa $\mathrm{ka}$ rang suwung dalam berbagai transformasinya di era kontemporer saat ini, dapat berwujud ruang terbuka dalam bentuk Ruang Terbuka Hijau (RTH), seperti: (1) taman kota, taman median, lapangan (alun-alun); (2) jalur hijau (sawah/ ladang); (3) sempadan/margin (bangunan, jalan, sungai, jurang, danau, dan pantai); (4) areal dalam radius kawasan suci pura (apenyengker, apenimpug, apeneleng alit-madia-agung) mengacu Bhisama PHDI Bali (25 Januari 1994); (5) batasan pemanfaatan ruang di atas ketinggian pohon kelapa ( \pm 15 meter) mengacu Perda No. 3/PD/DPRD/1974, tentang ketinggian bangunan; serta bentuk-bentuk aplikasi ruang dan regulasi lainnya.

Meskipun dalam praksisnya ruang-ruang tersebut mendapat tekanan berat oleh globalisasi era Kaliyuga ini dengan agen pariwisata dan modernitas. Perjuangan melalui pendekatan konservasi, revitalisasi, ataupun reformasi, guna mempertahankan eksistensi "nilai kekosongan" dalam bentuk ruang fisik (sekala) maupun ruang bathin (niskala) harus dilakukan sebagai jati diri orang Bali yang berfilosofi dan meyakini konsepsi hidup Hinduisme; demikian juga orang Bali non Hindu yang tinggal di Bali dan menggantungkan hidup dari alam Bali sudah sewajarnya menghormati langit yang dijunjungnya, dari tempat mereka berpijak saat ini. Tidak kalah penting juga peran orang luar Bali untuk menghormati keberadaan Bali (sosial, bu- daya "arsitektur", dan sumber daya) dengan segala keunikan tradisi dan laku agamanya.

\section{PENUTUP}

Pengembangan pemahaman ruang dalam arsitektur Bali sangat dipengaruhi oleh teologi, filosofi, dan konsep ajaran agama Hindu, dengan demikian eksistensi tata ruang Bali sejatinya adalah pembumian ideologi Hindu. Ajaran Hindu seperti: tat twam asi, bhuana agung - bhuana alit, panca maha bhuta, tri hita karana, tri bhuwana, purusha-pradhana, dan lainnya, menjadi prinsip praktis kearsitekturan, seperti, tri mandala, sanga mandala, tri angga, sukat 'ukuran', natah, ragam hias, warna, tekstur dan lainnya.

Spiritualitas ke-Hinduan dalam pola ruang dan tata bangunan arsitektur Bali diwujudkan dengan: (1) Penataan struktur fisik, bangunan, landsekap, kesesuaian antropometri pemilik, topografi, geografi, dan iklim setempat, serta estetika (bentuk olah yoga). (2) Beraneka makna dan simbol-simbol pada tata ruang dan fisik bangunannya (bentuk olah yantra, dan tantra). (3) Tata cara mendirikan bangunan, ritual yang menyertai selama masa pra konstruksi, konstruksi, dan pasca konstruksi sebagai bawa maurip 'sosok bangunan yang hidup' (bentuk olah mantra, dan mudra).

Ruang dalam wujud fisik (sekala) juga dihormati secara spirit (niskala) sebagai kekeran 'batasan keramat', sebagai kawasan suci (apenyengker, apenimpug, apeneleng). Hal terakhir ini yang sering tidak dipamahi dalam ranah materialistis, sehingga sering diserobot, dilanggar, untuk tujuan komodifikasi semata, padahal sudah diatur dalam bhisama maupun regulasi formal lainnya.

Perjuangan untuk pelestarian ruang-ruang ideal Bali harus terus dilakukan baik dengan pendekatan konservasi, revitalisasi, ataupun reformasi guna mempertahankan eksistensi nilai kekosongan yang bermakna ruang fisik maupun metafisik sebagai landasan kebudayaaan Bali. 


\section{DAFTAR PUSTAKA}

Adhika, I Made. 2012. Komodifikasi Kawasan Suci Pura Uluwatu. Denpasar: Udayana University Press.

Atmaja, Jiwa. 2003. Perempatan Agung (Catuspatha). Denpasar: CV. Bali Media Adhikarsa.

Gelebet, Nyoman, dkk. 2002. Arsitektur Tradisional Daerah Bali. Denpasar: Departemen Pendidikan dan Kebudayaan Proyek Inventarisasi dan Dokumentasi Kebudayaan Daerah.

Halim, Fachrizal A. 2002. Beragama dalam Belenggu Kapitalisme. Magelang: Indonesia Tera.

Reksohadiprodjo dan Karseno. 1993. Ekonomi Perkotaaan. Yogyakarta: BPFE.

Runa, I Wayan. 2008. Sejarah Arsitektur Tradisional Bali. Dalam Pustaka Arsitektur Bali. Sueca (ed.). Denpasar: Ikatan Arsitek Indonesia Daerah Bali.

Salain, Putu Rumawan. 2013. Arsitektur Posmo pada Masjid Al Hikmah dalam Serapan Arsitektur Tradisional Bali. Denpasar: Udayana University Press.

Suardana, I Nyoman Gde. 2015. Rupa Nir-Rupa Arsitektur Bali. Denpasar: Buku Arti.

Sudibya, Made Widnyana. 2008. "Mandala”. Dalam Pustaka Arsitektur Bali. (Ed.) Ngakan Putu Sueca. Denpasar: Ikatan Arsitek Indonesia Daerah Bali.

Sukawati, Tjok. A.A. Oka. 2004. Ubud Bergrak. Denpasar: Bali Media Adhikarsa.

Sulistyawati, Anastasia. 2013."Principles and Concepts of Balinese Traditional Architecture and Cultural Values". Dalam Vernacular Transformations Architecture, Place, and Tradition. (Ed.) Gusti Ayu Made Suartika. Denpasar: Pustaka Larasan.

Suyoga, I Putu Gede. 2016. “Teologi Arsitektur Bali”. Prosiding Seminar Nasional, Menggali dan Membangun Ilmu Teologi, Teologi Hindu dan Teologi Lokal dalam Perspektif Teologi Deterministik. Institut Hindu Dharma Negeri Denpasar. 27 Juni 2016. 